\title{
Analisis Daya Saing Kakao Olahan dan Faktor-Faktor yang Mempengaruhi Daya Saing Kakao Olahan Provinsi Sumatera Utara, Indonesia di Pasar Internasional
}

\author{
(The Competitiveness Analysis of Processed Cocoa and Factors Affecting the \\ Competitiveness of Processed Cocoa in North Sumatra Province, Indonesia \\ in the International Market)
}

\author{
Nelva Ginting», Rahmanta, Lindawati \\ Program Studi Magister Agribisnis, Fakultas Pertanian, Universitas Sumatera Utara, Medan; \\ •Email korespondensi: nelva.meyriani@gmail.com
}

\begin{abstract}
Increasing exports of processed cocoa (cocoa butter) from North Sumatra to the Malaysian and Singaporean markets will increase competitiveness. This potential provides added value for the national cocoa processing industry. The purpose of this research is to analyze the competitiveness of processed cocoa (cocoa butter) of North Sumatra in the international market, and to analyze the factors that influence the competitiveness of processed cocoa (cocoa butter) of North Sumatra in the markets of Malaysia and Singapore. The research method using Revealed Comparative Advantage (RCA) and Export Product Dynamic (EPD) analyzes the competitiveness of North Sumatran processed cocoa (cocoa butter) in the International Market. Multiple Linear Regression to analyze the factors that influence the competitiveness of processed cocoa (cocoa butter) of North Sumatra in the Malaysian and Singaporean markets. The results show that North Sumatra has strong competitiveness in the Malaysian and Singaporean markets. The factors that influence the competitiveness of processed cocoa (cocoa butter) in North Sumatra are the export volume of processed cocoa (cocoa butter) in North Sumatra, the domestic price for processed cocoa (cocoa butter) in North Sumatra, the export price for processed cocoa (cocoa butter) in North Sumatra, Export prices of processed cocoa (cocoa butter) from Ghana, the policy of exiting beans has a significant positive effect on the competitiveness of processed cocoa (cocoa butter) of North Sumatra to the Malaysian and Singaporean markets.
\end{abstract}

Keywords: competitiveness; competitiveness factor; processed cocoa

\begin{abstract}
Abstrak. Peningkatan ekspor kakao olahan (cocoa butter) Sumatera Utara ke pasar Malaysia dan Singapura akan meningkatkan daya saing. Potensi ini memberikan nilai tambah bagi industri pengolahan kakao nasional. Tujuan penelitian menganalisis daya saing kakao olahan (cocoa butter) Sumatera Utara di Pasar Internasional, menganalisis faktor-faktor yang berpengaruh terhadap daya saing kakao olahan (cocoa butter) Sumatera Utara di Pasar Malaysia dan Singapura. Metode penelitian menggunakan Revealed Comparative advantage (RCA) dan Export Product Dynamic (EPD) menganalisis daya saing kakao olahan (cocoa butter) Sumatera Utara di Pasar Internasional. Regresi Linear Berganda untuk menganalisis faktor yang berpengaruh terhadap daya saing kakao olahan(cocoa butter) Sumatera Utara di Pasar Malaysia dan Singapura. Hasil penelitian menunjukkan Sumatera Utara memiliki daya saing yang kuat di Pasar Malaysia dan Singapura. Faktor-faktor yang berpengaruh terhadap daya saing kakao olahan (cocoa butter) Sumatera Utara adalah volume ekspor kakao olahan (cocoa butter) Sumatera Utara, harga domestik kakao olahan (cocoa butter) Sumatera Utara, harga ekspor kakao olahan (cocoa butter) Sumatera Utara, harga ekspor kakao olahan (cocoa butter) Ghana, kebijakan bea keluar biji berpengaruh positif signifikan terhadap daya saing kakao olahan (cocoa butter) Sumatera Utara ke Pasar Malaysia dan Singapura.
\end{abstract}

Kata kunci: daya saing; faktor daya saing; kakao olahan

\section{PENDAHULUAN}

Komoditi kakao Sumatera Utara merupakan komoditi perkebunan yang berpotensi ekspor yang diharapkan dapat memenuhi permintaan pasar ekspor kakao (Arsyad, 2011). Sumatera Utara merupakan salah satu pusat perkebunan di Indonesia, produksi komoditi kakao
Sumatera Utara sangat berpotensi untuk dikembangkan. Permasalahan yang dihadapi dalam pengembangan kakao di Sumatera Utara adalah produktivitas kebun kakao masih rendah akibat serangan hama penggerek buah kakao (PBK), mutu produk masih rendah, pengembangan produk hulu dan hilir kakao 
belum optimal, kontinuitas pasokan kakao belum terpenuhi serta kurangnya penyuluhan kepada petani-petani kakao tentang cara pengolahan kakao menjadi produk olahan. Hal ini disebabkanoleh kesalahan pada petani kakao Sumatera Utara adalah tidak melakukan fermentasi pada biji kakao yang baru dipanen, seharusnya biji kakao yang telah dipanen difermentasi terlebih dahulu sebelum dilakukan pengeringan, umumnya petani kakao Sumatera Utara langsung melakukan pengeringan tanpa melalui proses fermentasi. Inilah yang membuat mutu biji kakao Sumatera Utara di perdagangan internasional menjadi rendah. Padahal biji kakao Sumatera Utara memiliki keunggulan melting point cocoa butter yang tinggi, serta tidak mengandung pestisida dibanding biji kakao dari Ghana maupun Pantai Gading. Sumatera Utara mengekspor kakao dalam bentuk biji kakao, produk setengah jadi yaitu cocoa butter, cocoa paste, cocoa powder, chocolate dan lainnya. Biji buah kakao/coklat dipakai sebagai bahan untuk membuat berbagai macam produk makanan dan minuman. Buah coklat/kakao tanpa biji dapat difermentasi untuk dijadikan pakan ternak. Pasar cokelat merupakan konsumen terbesar dari biji kakao dan produk setengah jadi seperti cocoa powder dan cocoa butter (Ragimun, 2012).

Pada tahun 2011-2020 terlihat bahwa ekspor kakao masih didominasi oleh biji kakao, belum produk olahan. Namun dapat kita lihat bahwa volume ekspor kakao olahan menunjukkan peningkatan, khususnya pada lemak kakao (cocoa butter). Setelah adanya penerapan bea keluar biji kakao, volume ekspor biji kakao menurun sangat signifikan namun disisi lain ekspor produk kakao olahan seperti pasta, lemak serta bubuk kakao mulai mengalami pergerakan cenderung meningkat setelah penerapan bea keluar biji kakao. Peningkatan ekspor kakao olahan terutama pada lemak kakao (cocoa butter) Sumatera Utara mengindikasi bahwa industri pengolahan kakao dalam negeri mulai mengalami peningkatan (Statistik Perdagangan Sumatera Utara, 2020). Pada umumnya kakao olahan yang biasa dikonsumsi industri makanan dan minuman adalah kakao olahan setengah jadi seperti lemak kakao, bubuk kakao, dan tepung kakao. Kakao olahan setengah jadi dapat digunakan sebagai bahan baku penunjang industri makanan dan minuman. Peningkatan ekspor kakao olahan juga didukung oleh konsumsi kakao olahan per kapita penduduk Indonesia tumbuh 10\% per tahun (Indonesia, 2019).

Kendala yang menghambat perkembangan kakao olahan di Sumatera Utara adalah sistem pengolahan kakao yang belum berkembang dengan baik, padahal Sumatera Utara memiliki banyak potensi untuk mengembangkan kakao olahan. Sehingga diperlukan kajian mengenai peningkatan daya saing kakao olahan (cocoa butter) Sumatera Utara, hal ini juga sesuai dengan penelitian mengenai daya saing yang menganalisis Peningkatan Daya Saing Ekspor Produk Olahan Kakao Indonesia di Pasar Internasional. Hasil penelitian menunjukkan bahwa produk olahan kakao Indonesia memiliki keunggulan komparatif pada komoditi biji kakao, pasta cokelat, lemak cokelat, dan bubuk cokelat tetapi tidak memiliki keunggulan komparatif pada komoditi cokelat. Dari hasil analisis RCA menunjukkan bahwa komoditi lemak cokelat Indonesia memiliki indeks RCA tertinggi dibandingkan produk olahan kakao lainnya (Andini et al., 2016). Peningkatan daya saing kakao olahan Sumatera Utara perlu didukung oleh peningkatan volume ekspor kakao olahan, harga domestik kakao olahan, harga ekspor kakao olahan, kebijakan bea keluar biji kakao hal ini sesuai dengan penelitian yang menganalisis faktor-faktor yang mempengaruhi dan upaya meningkatkan daya saing kakao Jawa Timur. Faktor yang mempengaruhi daya saing kakao olahan Jawa Timur secara signifikan yaitu volume ekspor, harga ekspor dan produktivitas kakao pada taraf 10\% (Harya, 2018).

Berdasarkan uraian latar belakang, maka penelitian ini penting dilakukan karena menganalisis daya saing yang dapat dilihat dari keunggulan komparatif dan keunggulan 
kompetitif sehingga dapat dilihat potensi daya saing kakao olahan (cocoa butter) Sumatera Utara di Pasar Internasional, hal ini berbeda dengan penelitian sebelumnya yang hanya menganalisis daya saing dengan melihat keunggulan komparatif saja.

Faktor-faktor yang mempengaruhi daya saing kakao olahan (cocoa butter) Provinsi Sumatera Utara di Pasar Malaysia dan Singapura menggunakan lima variabel yaitu volume ekspor kakao olahan (cocoa butter) Sumatera Utara, harga domestik kakao olahan (cocoa butter) Sumatera Utara, harga ekspor kakao olahan (cocoa butter) Sumatera Utara, harga ekspor kakao olahan (cocoa butter) Ghana, kebijakan bea keluar biji, pada penelitian ini variabel tersebut penting dianalisis karena dapat mengetahui kebijakan yang tepat digunakan untuk meningkatkan daya saing kakao olahan (cocoa butter) Sumatera Utara dalam pengembangan pengolahan kakao olahan (cocoa butter) Sumatera Utara, sedangkan penelitian sebelumnya hanya menggunakan tiga variabel yaitu volume ekspor, harga ekspor dan produktivitas kakao.

Tujuan penelitian ini adalah untuk menganalisis daya saing kakao olahan (cocoa butter) Sumatera Utara di Pasar Internasional, menganalisis faktor-faktor yang berpengaruh terhadap daya saing kakao olahan (cocoa butter) Sumatera Utara di Pasar Malaysia, dan menganalisis faktor-faktor yang berpengaruh terhadap daya saing kakao olahan (cocoa butter) Sumatera Utara di Pasar Singapura.

\section{METODE}

Analisis daya saing kakao olahan (cocoa butter) Sumatera Utara di Pasar Internasional dianalisis menggunakan Revealed Comparative advantage (RCA) untuk menganalisis keunggulan Komparatif dan Export Product Dynamic (EPD) untuk menganalisis keunggulan Kompetitif. Berikut rumus keunggulan komparatif dengan metode RCA ....... (1):

$\operatorname{RCA}=\frac{X i j / X * j}{X i w / X * w}$

Keterangan:

RCA = Angka Revealed Comparative Advantage (Indeks)

$\mathrm{X} \cdot \mathrm{j}=$ Nilai ekspor total Negara $\mathrm{j}$ (US\$)

Xiw =Nilai ekspor komoditas i dunia (US\$)

$\mathrm{X} \cdot \mathrm{w}=$ Nilai ekspor total Dunia (US\$)

Penilaian RCA adalah sebagai berikut:

1. Nilai RCA > 1, maka Sumatera Utara memiliki keunggulan komparatif diatas rata-rata dunia sehingga kakao olahan (cocoa butter) Sumatera Utara memiliki daya saing kuat.

2. Nilai RCA < 1, maka Sumatera Utara memiliki keunggulan komparatif di bawah rata-rata dunia sehingga kakao olahan (cocoa butter) Sumatera Utara memiliki daya saing lemah.

Keunggulan kompetitif dianalisis menggunakan metode Export Product Dynamic (EPD). Matriks posisi daya saing pada masing-masing kuadran dengan sumbu $\mathrm{X}$ sebagai pangsa pasar ekspor dan sumbu y sebagai pangsa pasar produk tersaji pada gambar 1 .

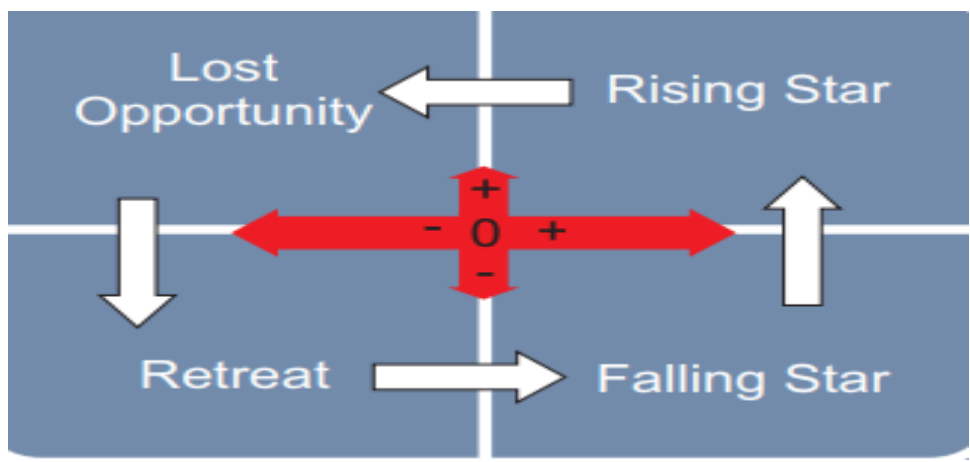

Sumber : Bappenas, 2009

Gambar 1. Matriks posisi daya saing (Export Product Dynamic (EPD)) 
Posisi dalam kuadran menggambarkan kekuatan bisnis (sumbu X) dan daya tarik pasar (sumbu Y) produk dirumuskan sebagai berikut (Abdullah, P., Alisjahbana, Armida, S., Effendi, N., 2002) (2):

\section{Sumbu X}

$\frac{\sum_{t=1}^{n}\left(\frac{X i j}{W i j}\right)_{t} \times 100 \%-\sum_{t=1}^{n}\left(\frac{X i j}{W i j}\right)_{t-1} \times 100 \%}{T}$

\section{Sumbu Y}

$\frac{\sum_{t=1}^{n}\left(\frac{X t}{W t}\right)_{t} \times 100 \%-\sum_{t=1}^{n}\left(\frac{X t}{W t}\right)_{t-1} \times 100 \%}{T}$

Keterangan:

Xij = Nilai ekspor Kakao Olahan (cocoa butter) Sumatera Utara, Ghana, Pantai Gading ke Malaysia dan Singapura

$\mathrm{Xt}=$ Nilai ekspor total Sumatera Utara, Ghana, Pantai Gading ke Pasar Malaysia dan Singapura

Wij = Nilai ekspor Kakao Olahan (cocoa butter) Dunia ke Pasar Malaysia dan Singapura

$\mathrm{Wt}=$ Nilai ekspor total dunia ke Pasar Malaysia dan Singapura

$\mathrm{T}=$ Jumlah tahun yang diteliti

Ada 4 kategori indikator keunggulan kompetitif yaitu Rising Star mengacu pada pertumbuhan pangsa pasar komoditas dan total pangsa pasar negara dalam perdagangan dunia yang menunjukkan pangsa ekspor negara tersebut di pasar dunia semakin meningkat. Lost Opportunity menunjukkan bahwa pangsa pasar komoditas sedang mengalami penurunan sementara total pangsa pasar negara telah mengalami pertumbuhan perdagangan dunia. Falling Star menunjukkan bahwa terjadi peningkatan pangsa pasar komoditi, akan tetapi mengalami penurunan pada pangsa pasar totalnya dalam perdagangan dunia, maka dikatakan negara mampu memanfaatkan pasar tersebut dengan baik Posisi ini juga tidak diinginkan walaupun tidak seperti kondisi Lost Opportunity, karena pangsa pasarnya meningkat meskipun bukan pada pangsa pasar totalnya di pasar dunia (Abdullah, P., Alisjahbana, Armida, S.,
Effendi, N., 2002)

Faktor-faktor yang mempengaruhi daya saing Kakao Olahan Sumatera Utara di Pasar Malaysia menggunakan regresi linear berganda dengan SPSS 24. ....... (3):

$\mathrm{RCAMalaysia}=\alpha_{0}+\alpha_{1} \mathrm{X}_{1 \mathrm{it}}+\alpha_{2} \mathrm{X}_{2 \mathrm{it}}+\alpha_{3} \mathrm{X}_{3 \mathrm{it}}$

$$
+\alpha_{4} \mathrm{X}_{4 i \mathrm{t}}+\alpha_{5} \mathrm{X}_{5 \mathrm{it}}
$$

RCA $_{\text {Malaysia }}=$ Daya Saing Kakao Olahan Sumatera Utara ke Malaysia

$\mathrm{X}_{1}=$ Volume Ekspor Kakao Olahan (cocoa butter) Sumatera Utara (Ton)

$\mathrm{X}_{2}=$ Harga Domestik Kakao Olahan (cocoa butter) Sumatera Utara (Rp/Kg)

$\mathrm{X}_{3}=$ Harga Ekspor Kakao Olahan (cocoa butter) Sumatera Utara (US\$/Ton)

$\mathrm{X}_{4}=$ Harga Ekspor Kakao Olahan (cocoa butter) Pantai Gading (US\$/Ton)

$\mathrm{X}_{5}=$ Kebijakan Bea Keluar

$\alpha_{1}-\alpha_{5}=$ Koefisien Regresi

$\mathrm{t} \quad=$ Jumlah waktu (30 tahun (1991-2020))

Faktor-faktor yang mempengaruhi daya saing Kakao Olahan Sumatera Utara di Pasar Singapura menggunakan regresi linear berganda dengan SPSS 24....... (4):

$\mathbf{R C A}_{\text {Singapura }}=\beta_{0}+\beta_{1} X_{1 i} t+\beta_{2} X_{2 i t}+\beta_{3} X_{3 i t}$ $+\beta_{4} X_{4 i t}+\beta_{5} X_{5 i t}$

$\mathrm{RCA}_{\text {Singapura }}=$ Daya Saing Kakao Olahan Sumatera Utara ke Singapura

$\mathrm{X}_{1}=$ Volume Ekspor Kakao Olahan (cocoa butter) Sumatera Utara (Ton)

$\mathrm{X}_{2}=$ Harga Domestik Kakao Olahan (cocoa butter) Sumatera Utara (Rp/Kg)

$\mathrm{X}_{3}=$ Harga Ekspor Kakao Olahan (cocoa butter) Sumatera Utara (US\$/Ton)

$\mathrm{X}_{4}=$ Harga Ekspor Kakao Olahan (cocoa butter) Pantai Gading (US\$/Ton)

$\mathrm{X}_{5}=$ Kebijakan Bea Keluar

$\beta_{1}-\beta_{5}=$ Koefisien Regresi

$\mathrm{t}=$ Jumlah waktu (30 tahun (1991-2020))

I. Uji Asumsi Klasik yang digunakan adalah uji heteroskedastisitas (signifikansi lebih besar dari 0.05), uji multikolinearitas 
(VIF $>10$, dan nilai tolerance $<0.10$ ), uji normalitas dengan nilai KolmogorovSmirnov signifikan $(\mathrm{p}>0,05)$, uji autokorelasi menggunakan Run Test dengan nilai Asymp.Sig (2-tailed) lebih besar dari tingkat signifikansi 0,05 (Ghozali, 2006).

II. Pengujian Hipotesis menggunakan Uji F (F hitung > Ftabel) untuk melihat semua variabel independen secara serentak dan signifikan mempengaruhi variabel dependen. Goodness of Fit hubungan variabel independen dengan variabel dependen. Uji $\mathrm{t}$ (nilai signifikan < 0.05) (Ghozali, 2006).

\section{HASIL DAN PEMBAHASAN}

\section{Daya Saing Kakao Olahan (Cocoa Butter) Sumatera Utara di Pasar Internasional}

Daya saing dapat dilihat dari pangsa pasar, jika pangsa pasar suatu komoditi meningkat,artinya daya saing meningkat. Produk kakao memiliki struktur pasar yang berbeda, dimana produk kakao Indonesia secara umum cenderung ke arah pasar persaingan sempurna dan produk kakao lainnya cenderung ke arah pasar oligopoli. Indonesia memiliki keunggulan kompetitif yang tinggi dan memiliki posisi ideal pasar dimana perdagangan produk tersebut sedang mengalami tambahan pangsa pasar yang tumbuh dengan pesat (Hanafi \& Tinaprilla, 2017). Daya saing dapat dilihat dari pangsa pasar, jika pangsa pasar suatu komoditi meningkat,artinya daya saing meningkat. Daya saing dapat dilihat dari keunggulan komparatif dan keunggulan kompetitif.

Keunggulan Komparatif (RCA) Kakao Olahan (Cocoa Butter)Sumatera Utara, Ghana dan Pantai Gading

Keunggulan komparatif (produktivitas) merupakan konsep bahwa suatu daerah atau tempat yang tidak memiliki keunggulan, dapat melakukan produksi atau ekspor pada produk yang memiliki keunggulan komparatif terkecil (Asmarantaka, 2012). Secara umum David Ricardo mendasarkan teorinya pada sejumlah asumsi yang disederhanakan, yaitu hanya terdapat dua negara dan dua barang, perdagangan bersifat bebas, terdapat mobilitas tenaga kerja yang sempurna di dalam negara namun tidak ada mobilitas antara dua negara, biaya produksi konstan, tidak ada biaya transportasi, tidak ada perubahan teknologi (Badry, 2013). Keunggulan komparatif kakao olahan (cocoa butter) Sumatera Utara diukur menggunakan RCA. Jika nilai RCA > 1 menunjukkan kakao olahan (cocoa butter) mempunyai keunggulan komparatif diatas rata- rata( dunia) ataupun berdaya saing kuat. Jika nilai RCA $<1$ menunjukkan kakao olahan (cocoa butter) mempunyai keunggulan komparatif di bawah rata-rata (dunia) ataupun berdaya saing lemah.

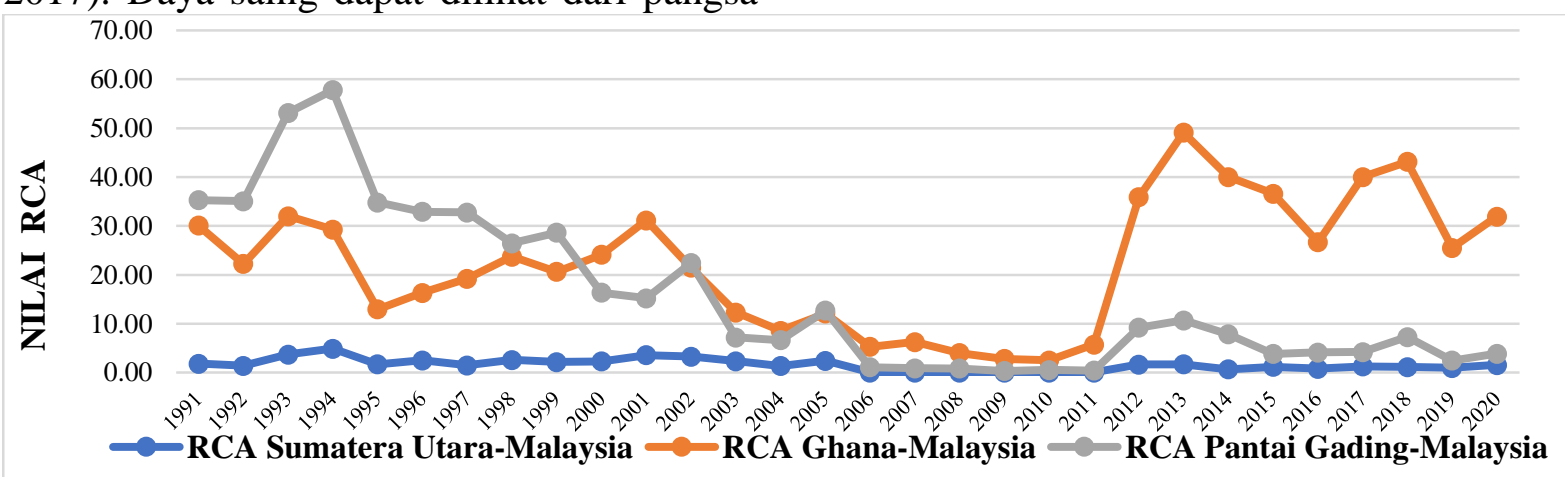

Sumber :Data Diolah (2021)

Gambar 2. Daya saing (RCA) kakao olahan (cocoa butter) ke pasar Malaysia

Gambar 2 menunjukkan nilai RCA kakao olahan (cocoa butter) Sumatera Utara ke Pasar Malaysia lebih besar dari satu yaitu 1.64, artinya Sumatera Utara mempunyai keunggulan komparatif dan kakao olahan (cocoa butter) Sumatera Utara berdaya saing kuat di pasar Malaysia. Ghana memiliki ratarata nilai RCA lebih besar dari satu sebesar 
22.39 ke Pasar Malaysia, hal ini menunjukkan bahwa daya saing kakao olahan (cocoa butter) Ghana berada jauh di atas rata-rata dunia, artinya kakao olahan (cocoa butter) Ghana berdaya saing kuat di pasar Malaysia.
Pantai Gading memiliki rata-rata nilai RCA lebih besar dari satu sebesar 15.84, artinya kakao olahan (cocoa butter) Pantai Gading berdaya saing kuat di pasar Malaysia.

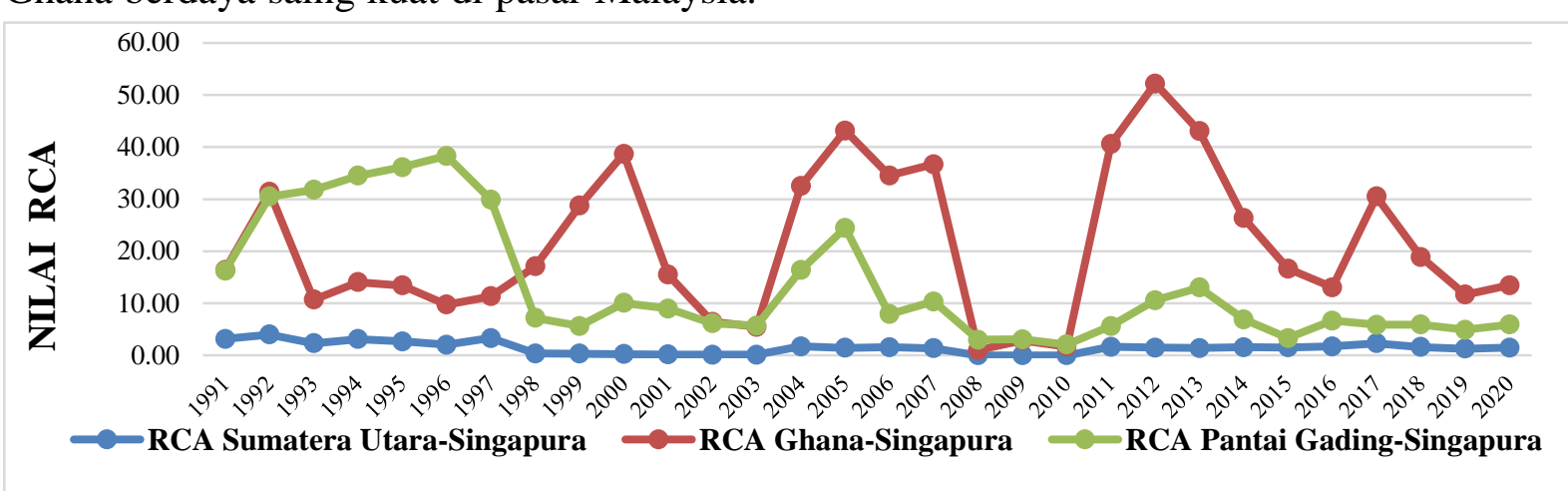

Sumber : Data Diolah (2021)

Gambar 3. Daya saing (RCA) kakao olahan (Cocoa Butter) ke pasar Singapura

Gambar 3 menunjukkan nilai RCA kakao olahan (cocoa butter) Sumatera Utara ke Pasar Singapura lebih besar dari satu yaitu 1.47, artinya Sumatera Utara mempunyai keunggulan komparatif dan kakao olahan (cocoa butter) Sumatera Utara berdaya saing kuat di pasar Singapura. Ghana memiliki ratarata nilai RCA lebih besar dari satu sebesar 21.26 ke Pasar Singapura, hal ini menunjukkan bahwa daya saing kakao olahan (cocoa butter) Ghana berada jauh di atas ratarata dunia, artinya kakao olahan (cocoa butter) Ghana berdaya saing kuat di pasar Singapura. Pantai Gading memiliki rata-rata nilai RCA lebih besar dari satu sebesar 13.24, artinya kakao olahan (cocoa butter) Pantai Gading berdaya saing kuat di pasar Singapura.

Nilai RCA Ghana dan Pantai Gading sangat tinggi dibandingkan dengan nilai RCA Sumatera Utara karena kualitas kakao olahan (cocoa butter) yang dihasilkan baik, keberlanjutan pasokan, kebijakan-kebijakan internasional yang memberikan kemudahan bagi negara importir. Namun Sumatera Utara juga tetap dapat bersaing dengan Ghana dan Pantai Gading dengan meningkatkan kualitas kakao olahan (cocoa butter) karena kakao olahan (cocoa butter) yang dihasilkan Sumatera Utara memiliki keunggulan melting point cocoa butter yang tinggi dibandingkan dengan cocoa butter dari negara Ghana dan Pantai Gading.

Namun Sumatera Utara juga tetap dapat bersaing dengan Ghana dan Pantai Gading dengan meningkatkan kualitas kakao olahan (cocoa butter) karena kakao olahan (cocoa butter) yang dihasilkan Sumatera Utara memiliki keunggulan melting point cocoa butter yang tinggi artinya cocoa butter yang dihasilkan Sumatera Utara tidak mudah meleleh dibandingkan dengan cocoa butter dari negara Ghana dan Pantai Gading, sehingga kakao olahan (cocoa butter) Sumatera Utara tetap disukai negara importir seperti Malaysia dan Singapura. Hasil penelitian ini sesuai dengan penelitian (Aulia et al., 2018) yang menyatakan bahwa nilai RCA menunjukkan daya saing Indonesia kuat untuk komoditi kulit kakao, pasta kakao, lemak kakao.

\section{Keunggulan Kompetitif (EPD) Kakao Olahan (Cocoa Butter) Sumatera Utara, Ghana dan Pantai Gading}

Keunggulan kompetitif diperoleh jika perusahaan melaksanakan strategi penciptaan nilai secara tidak serentak dengan strategi yang diimplementasikan oleh pesaing yang sekarang ada atau pesaing potensial (Amirullah, 2015). Keunggulan kompetitif kakao olahan (cocoa butter) dari Sumatera Utara, Ghana, Pantai Gading ke 
Pasar Malaysia dan Singapura menggunakan metode Export Product Dynamic (EPD). Metode Export Product Dynamics (EPD) memiliki empat kuadran yang mewakili posisi pangsa pasar kakao olahan (cocoa butter). Kuadran I (Rising Star),. Kuadran II (Lost Opportunity), Kuadran III (Retreat), Kuadran IV (Falling Star).

Tabel 2. Nilai EPD kakao olahan (cocoa butter) Sumatera Utara, Ghana, Pantai Gading ke pasar Malaysia dan Singapura

\begin{tabular}{|c|c|c|c|c|}
\hline \multirow{2}{*}{\multicolumn{2}{|c|}{ Pasar Tujuan Ekspor Kakao Olahan (cocoa butter) }} & \multicolumn{2}{|c|}{ Nilai Posisi $(\mathrm{X}, \mathrm{Y})$} & \multirow{2}{*}{$\begin{array}{c}\text { Kategori } \\
\text { Posisi }\end{array}$} \\
\hline & & $\mathbf{X}$ & $\mathbf{Y}$ & \\
\hline \multirow{3}{*}{ EPD ke Pasar Malaysia } & $\begin{array}{c}\text { Sumatera Utara- } \\
\text { Malaysia }\end{array}$ & 0.000166663 & $9.74316 \mathrm{E}-05$ & Rising Star \\
\hline & Ghana-Malaysia & 0.000328434 & $2.47515 \mathrm{E}-06$ & Rising Star \\
\hline & Pantai Gading-Malaysia & -0.000124223 & $1.23981 \mathrm{E}-05$ & $\begin{array}{c}\text { Lost } \\
\text { Opportunity }\end{array}$ \\
\hline \multirow{3}{*}{ EPD ke Pasar Singapura } & $\begin{array}{c}\text { Sumatera Utara- } \\
\text { Singapura }\end{array}$ & 9.31993E-05 & -0.00107409 & Falling Star \\
\hline & Ghana-Singapura & 0.000947101 & 0.000124944 & Rising Star \\
\hline & Pantai Gading-Singapura & -0.000716357 & $-6.78494 \mathrm{E}-05$ & Retreat \\
\hline
\end{tabular}

Sumber : Data diolah (2021)

Tabel 2 menunjukkan bahwa nilai posisi EPD kakao olahan (cocoa butter) Sumatera Utara ke Pasar Malaysia, Ghana ke Pasar Malaysia, Ghana ke Pasar Singapura adalah bernilai positif pada posisi X dan Y sehingga berada pada posisi Rising Star. Nilai EPD kakao olahan (cocoa butter) Pantai Gading ke Pasar Malaysia bernilai negatif untuk posisi $\mathrm{X}$ dan positif pada posisi Y sehingga berada pada posisi Lost Opportunity. Nilai EPD kakao olahan (cocoa butter) Sumatera Utara ke Pasar Singapura bernilai negatif pada posisi $\mathrm{X}$ dan Y sehingga berada pada posisi Falling Star. Posisi daya saing (keunggulan kompetitif) kakao olahan (cocoa butter) Sumatera Utara, Ghana, Pantai Gading ke Pasar Malaysia dan Singapura pada tahun 1991-2021 dapat dilihat pada Gambar 4.

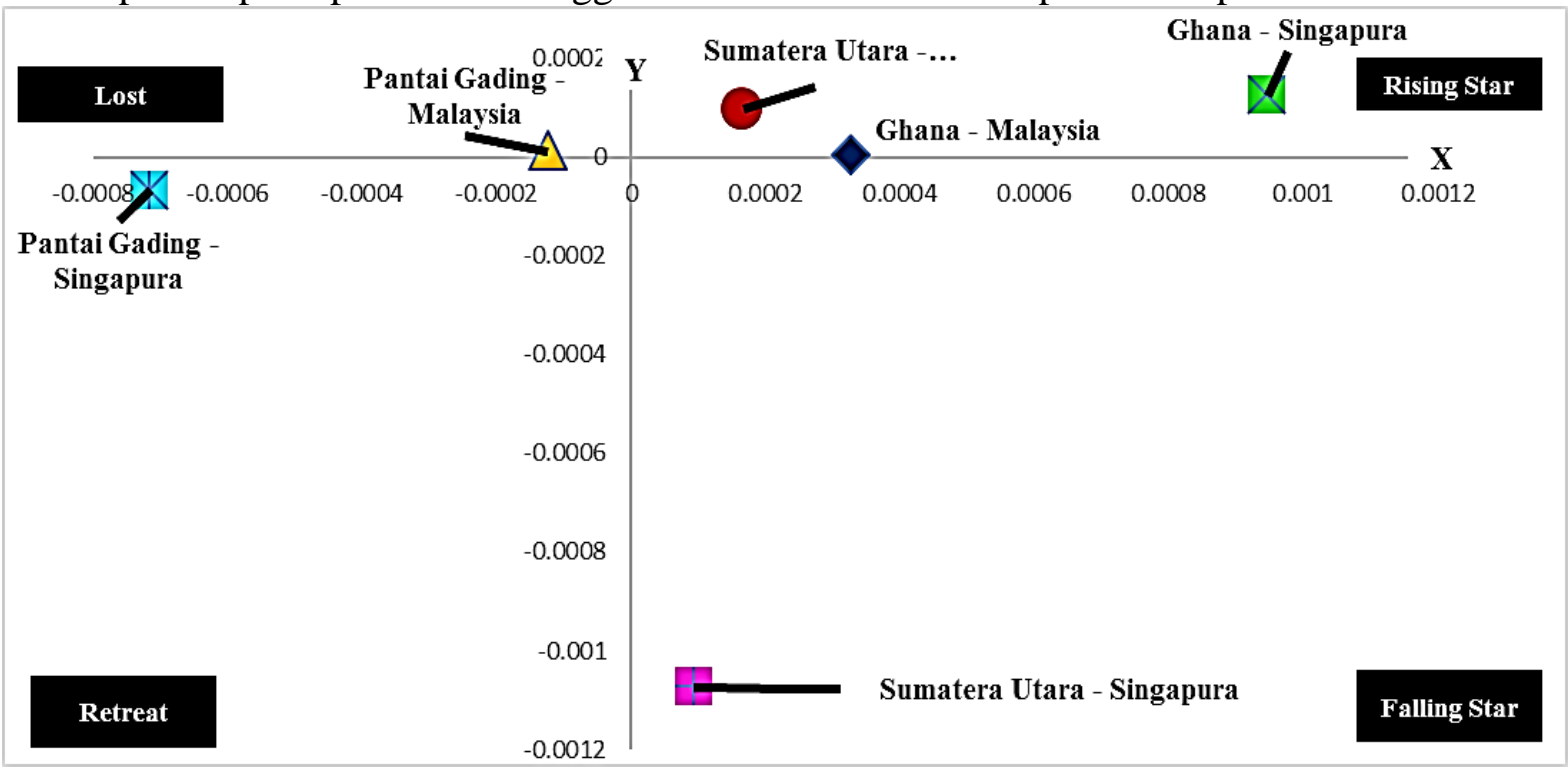

Sumber : Data Diolah (2021)

Gambar 4. Posisi Daya Saing kakao olahan (cocoa butter) Sumatera Utara, Ghana, Pantai Gading di Pasar Malaysia dan Singapura

Gambar 4 menunjukkan keunggulan kompetitif kakao olahan (cocoa butter) Sumatera Utara ke Pasar Malaysia, Ghana ke Pasar Malaysia dan Ghana ke Pasar

Singapura berada di kuadran I atau rising star dengan pangsa pasar ekspor dan produknya bernilai positif (berdaya saing) dan kakao olahan (cocoa butter) yang di produksi 
Sumatera Utara dan Ghana ke Pasar Malaysia maupun Ghana ke Pasar Singapura adalah produk yang dinamis atau memiliki pertumbuhan pangsa pasar yang lebih cepat dari rata-rata semua produk.

Keunggulan kompetitif Pantai Gading ke Pasar Malaysia berada pada kuadran II atau lost opportunity dimana pertumbuhan pangsa pasar ekspor yang negatif namun pertumbuhan pangsa produknya positif, Pantai Gading kehilangan pangsa pasar kakao olahan (cocoa butter) di Pasar Malaysia (tidak memiliki keunggulan kompetitif) namun produknya memiliki pertumbuhan pangsa pasar produk yang tumbuh lebih cepat dari rata-rata semua produk (dinamis). Posisi tersebut adalah posisi yang paling tidak diinginkan, selain itu produk ini juga mengalami penurunan nilai yang ditunjukkan pertumbuhan pangsa pasar ekspornya yang negatif. Keunggulan kompetitif Pantai Gading ke Pasar Singapura berada pada kuadran III atau retreat yaitu Pantai Gading memiliki produk kakao olahan (cocoa butter) yang stagnan di Singapura. Produk yang stagnan menunjukkan pangsa pasar produk yang tumbuh tidak lebih cepat dari rata-rata semua produk. Daya saing (keunggulan kompetitif) kakao olahan (cocoa butter)
Sumatera Utara ke Pasar Singapura menempati posisi kuadran IV atau falling star. Pada kuadran ini kakao olahan (cocoa butter) unggul secara kompetitif atau berdaya saing, namun bukan pada produk yang tergolong dinamis. Pertumbuhan pangsa pasar ekspornya positif namun pangsa pasar produknya negatif yang juga menunjukkan bahwa nilai ekspor seluruh komoditas Sumatera Utara ke Singapura cenderung menurun jika dibandingkan dengan nilai ekspor total dunianya karena pangsa pasar produk yang negatif. Hasil penelitian ini sesuai dengan penelitian (Hanafi \& Tinaprilla, 2017) yang menyatakan bahwa Indonesia memiliki keunggulan kompetitif yang tinggi untuk biji kakao, pasta kakao, lemak kakao dan bubuk kakao.

\section{Faktor-Faktor yang berpengaruh terhadap Daya Saing (RCA) Kakao Olahan (Cocoa Butter) Sumatera Utara ke Pasar Malaysia}

Hasil uji regresi linear berganda untuk menganalisis faktor-faktor yang mempengaruhi daya saing (RCA) kakao olahan (cocoa butter) Sumatera Utara di Pasar Malaysia. Persamaan regresi linear berganda sebagai berikut :

Tabel 3. Hasil regresi linear berganda faktor yang mempengaruhi daya saing kakao olahan (cocoa butter) Sumatera Utara di pasar Malaysia

\begin{tabular}{lcccc}
\hline \multicolumn{1}{c}{ Variabel Bebas } & $\begin{array}{c}\text { Koefisien } \\
\text { Regresi }\end{array}$ & T-Hitung & Sig. & Keterangan \\
\hline Konstanta & 5.727 & 2.902 & .376 & \\
Volume Ekspor Kakao Olahan Sumut- & 1.083 & 3.920 & .037 & Signifikan \\
Malaysia (X1) & & & & \\
Harga Domestik Kakao Olahan Sumut (X2) & 0.501 & 2.741 & .026 & Signifikan \\
Harga Ekspor Kakao Olahan Sumut- & 1.298 & 2.275 & .032 & Signifikan \\
Malaysia (X3) & & & & \\
Harga Ekspor Kakao Olahan Ghana- & 1.447 & 2.095 & .042 & Signifikan \\
Malaysia (X4) & & & & \\
Tarif Bea Keluar biji kakao (X5) & 0.237 & 2.323 & .017 & Signifikan \\
\hline $\mathrm{R}^{2} \quad=0.653$ & & & & \\
F-Hitung =9.033 & & & & \\
Sig. =0.000 & & & & \\
\hline Simber: Data & & &
\end{tabular}

Sumber : Data diolah (2021)

\section{$\operatorname{LnX}_{2}$}

$$
\mathrm{RCA}_{\text {Malaysia }}=5.727-1.083 \operatorname{LnX}_{1}+0.501
$$

$$
\begin{aligned}
& +1.298 \mathrm{LNX}_{3}+1.447 \mathrm{LnX}_{4}+ \\
& 0.237 \operatorname{LnX}_{5}
\end{aligned}
$$

Hasil regresi berpengaruh secara parsial maupun simultan. Secara keseluruhan variabel $\mathrm{X}_{1}-\mathrm{X}_{5}$ berpengaruh secara simultan terhadap daya saing kakao olahan (cocoa butter) 
Sumatera Utara ke Pasar Malaysia. Hasil uji menghasilkan nilai $\mathrm{F}$ hitung $>\mathrm{F}$ tabel $(9.033$ $>$ 2.60) dan nilai Probabilitas F lebih kecil dibanding tingkat alpha 5\%, maka dapat disimpulkan bahwa variabel volume ekspor kakao olahan (cocoa butter) Sumatera Utara (X1), harga domestik kakao olahan (cocoa butter) Sumatera Utara (X2), harga ekspor kakao olahan (cocoa butter) Sumatera Utara (X3), harga ekspor kakao olahan (cocoa butter) Ghana (X4), kebijakan Bea Keluar biji kakao (X5) secara serempak berpengaruh signifikan terhadap variabel dependen yaitu daya saing (RCA) kakao olahan (cocoa butter) Sumatera Utara ke Pasar Malaysia.

Volume ekspor kakao olahan (cocoa butter) Sumatera Utara menunjukkan pengaruh positif dengan nilai koefisien regresi sebesar 1.083 artinya jika volume ekspor kakao olahan (cocoa butter) Sumatera Utara meningkat sebesar 1 ton ceteris paribus maka akan meningkatkan daya saing kakao olahan (cocoa butter) Sumatera Utara ke Pasar Malaysia sebesar 1.083 persen. Hasil penelitian ini sesuai dengan penelitian yang dilakukan oleh (Maulana \& Kartiasih, 2017) yang menyatakan bahwa volume ekspor kakao olahan berpengaruh positif terhadap daya saing kakao olahan. Hal ini menunjukkan bahwa dengan meningkatnya daya saing ekspor kakao olahan Indonesia ke negara tujuan utama ekspor, maka kakao olahan Indonesia akan lebih diminati oleh konsumen, sehingga akan meningkatkan permintaan kakao olahan oleh negara tujuan ekspor.

Harga domestik kakao olahan (cocoa butter) Sumatera Utara menunjukkan pengaruh positif dengan nilai koefisien regresi sebesar 0.501, artinya jika harga domestik meningkat sebesar Rp 1/ton ceteris paribus maka akan meningkatkan daya saing kakao olahan (cocoa butter) Sumatera Utara ke Pasar Malaysia sebesar 0.501 persen. Hasil penelitian ini sesuai dengan penelitian (Kalaba, 2012) yang menyatakan bahwa Harga domestik pasta kakao berpengaruh positif terhadap daya saing pasta kakao. Kenaikan harga domestik mendorong produsen lokal lebih meningkatkan jumlah produksinya dan memperhatikan kualitas pasta kakao, sehingga pasta kakao mendapat tempat di pasar internasional. Efek dari peningkatan harga domestik tersebut akan meningkatkan pendapatan yang kemudian meningkatkan daya saing pasta kakao naik. Kenaikan harga domestik pasta kakao Indonesia masih diikuti oleh peningkatan daya saing, hal ini disebabkan karena pada saat yang sama terjadi peningkatan harga domestik pasta kakao di negara-negara pesaing ekspor seperti di Amerika, Malaysia, dan Eropa. Dengan demikian daya saing pasta kakao Indonesia masih relatif tinggi.

Harga ekspor kakao olahan (cocoa butter) Sumatera Utara menunjukkan pengaruh positif dengan nilai koefisien regresi sebesar 1.298, artinya jika harga ekspor kakao olahan (cocoa butter) Sumatera Utara mengalami peningkatan sebesar $1 \mathrm{USD} /$ ton ceteris paribus maka akan meningkatkan daya saing kakao olahan (cocoa butter) Sumatera Utara ke Pasar Malaysia sebesar 1.298 persen. Hasil penelitian ini sesuai dengan penelitian (Musfiah, 2019) yang menyatakan bahwa Harga internasional kakao berpengaruh signifikan positif terhadap daya saing kakao Indonesia. Hal ini sesuai dengan teori hukum penawaran yang menyatakan bahwa harga dan produk yang ditawarkan berhubungan positif artinya apabila harga yang suatu produk meningkat maka barang yang ditawarkan produsen juga meningkat dan sebaliknya apabila harga produk turun maka penawaran juga akan turun. Para produsen akan meningkatkan produksinya karena akan mendapatkan keuntungan yang lebih. Sehingga dapat dikatakan bahwa meningkatnya harga internasional kakao akan menyebabkan ekspor kakao Indonesia meningkat pula dan daya saing kakao Indonesia juga akan meningkat.

Harga ekspor kakao olahan (cocoa butter) Ghana menunjukkan pengaruh positif dengan nilai koefisien regresi sebesar 1.447 , artinya jika harga ekspor kakao olahan (cocoa butter) Ghana mengalami peningkatan sebesar 1 USD/ton ceteris paribus maka akan 
meningkatkan daya saing kakao olahan (cocoa butter) Sumatera Utara ke Pasar Malaysia sebesar 1.447 persen. Hasil penelitian ini sesuai dengan penelitian (Tresliyana et al., 2018) yang menjelaskan bahwa Terdapat hubungan yang cukup tinggi antara daya saing biji kakao Indonesia dengan Ghana, dan daya saing kakao pasta Indonesia dengan Malaysia dan Belanda dalam perebutan pangsa pasar dunia. Hubungan tersebut semuanya positif dan ketiga negara eksportir tersebut memperebutkan pasar yang sama dengan Indonesia. Di pasar kakao butter dan kakao powder, Indonesia tidak memiliki korelasi dengan negara eksportir lainnya.

Kebijakan bea keluar menunjukkan pengaruh positif dengan nilai koefisien regresi sebesar 0.237, artinya adanya kebijakan bea keluar, maka akan meningkatkan daya saing kakao olahan (cocoa butter) Sumatera Utara ke Pasar Malaysia sebesar 0.237 persen. Hasil penelitian ini sesuai dengan penelitian
(Makmun, 2012) yang menyatakan bahwa penerapan kebijakan bea keluar biji kakao berdampak positif terhadap upaya pengembangan (daya saing) industri hilir pengolahan kakao di dalam negeri. Pasca penerapan kebijakan bea keluar biji kakao, jumlah perusahaan industri cacao processing terus mengalami peningkatan. Fenomena beroperasinya kembali perusahaan dibidang cacao processing. Selain mendorong beroperasinya kembali industri pengolahan kakao di dalam negeri, penerapan bea keluar biji kakao juga telah mendorong sejumlah investor asing untuk berinvestasi di Indonesia

Faktor-Faktor yang berpengaruh terhadap Daya Saing (RCA) Kakao Olahan (Cocoa Butter) Sumatera Utara ke Pasar Singapura

Hasil uji regresi linear berganda untuk menganalisis faktor-faktor yang mempengaruhi daya saing (RCA) kakao olahan (cocoa butter) Sumatera Utara di Pasar Singapura. Persamaan regresi linear berganda sebagai berikut :

Tabel 4. Hasil regresi linear berganda faktor yang mempengaruhi daya saing kakao olahan (cocoa butter) Sumatera Utara di pasar Singapura

\begin{tabular}{lcccc}
\hline \multicolumn{1}{c}{ Variabel Bebas } & $\begin{array}{c}\text { Koefisien } \\
\text { Regresi }\end{array}$ & T-Hitung & Sig. & Keterangan \\
\hline Konstanta & 23.780 & 2.676 & 0.107 & \\
$\begin{array}{l}\text { Volume Ekspor Kakao Olahan Sumut- } \\
\text { Singapura (X1) }\end{array}$ & 1.188 & 2.862 & 0.002 & Signifikan \\
$\begin{array}{l}\text { Harga Domestik Kakao Olahan Sumut } \\
\text { (X2) }\end{array}$ & 0.282 & 3.425 & 0.000 & Signifikan \\
$\begin{array}{l}\text { Harga Ekspor Kakao Olahan Sumut- } \\
\text { Singapura(X3) }\end{array}$ & 0.842 & 2.092 & 0.035 & Signifikan \\
$\begin{array}{l}\text { Harga Ekspor Kakao Olahan Ghana- } \\
\text { Singapura(X4) }\end{array}$ & 1.017 & 2.131 & 0.028 & Signifikan \\
Tarif Bea Keluar biji kakao (X5) & 0.728 & 2.096 & 0.015 & Signifikan \\
\hline $\begin{array}{l}\mathrm{R}^{2} \quad 0.560 \\
\text { F-Hitung = }\end{array}$ & & & & \\
Sig. $\quad=0.000$ & & & & \\
\hline
\end{tabular}

Sumber : Data diolah (2021)

$$
\begin{aligned}
\text { RCA }_{\text {Singapura }}= & 23.780+1.188 \operatorname{LnX}_{1}+0.282 \\
& \operatorname{LnX}_{2}+0.842 \operatorname{LNX}_{3}+1.017 \\
& \operatorname{LnX}_{4}+0.728 \operatorname{LnX}_{5}
\end{aligned}
$$

Hasil regresi berpengaruh secara parsial maupun simultan. Secara keseluruhan variabel $\mathrm{X}_{1}-\mathrm{X}_{5}$ berpengaruh secara simultan terhadap daya saing kakao olahan (cocoa butter) Sumatera Utara ke Pasar Singapura. Hasil uji menghasilkan nilai $\mathrm{F}$ hitung $>\mathrm{F}$ tabel $(4.697>2.60)$ dan nilai Probabilitas F lebih kecil dibanding tingkat alpha 5\%, maka dapat disimpulkan bahwa variabel volume ekspor kakao olahan (cocoa butter) Sumatera Utara (X1), harga domestik kakao olahan (cocoa butter) Sumatera Utara (X2), harga ekspor kakao olahan (cocoa butter) Sumatera Utara (X3), harga ekspor kakao olahan (cocoa butter) Ghana (X4), kebijakan Bea Keluar biji 
kakao (X5) secara serempak berpengaruh signifikan terhadap variabel dependen yaitu daya saing (RCA) kakao olahan (cocoa butter) Sumatera Utara ke Pasar Singapura.

Volume ekspor kakao olahan (cocoa butter) Sumatera Utara menunjukkan pengaruh positif dengan nilai koefisien regresi sebesar 1.188 artinya jika volume ekspor kakao olahan (cocoa butter) Sumatera Utara meningkat sebesar 1 ton ceteris paribus maka akan meningkatkan daya saing kakao olahan (cocoa butter) Sumatera Utara ke Pasar Singapura sebesar 1.188 persen Hasil penelitian ini sesuai dengan penelitian (Maulana \& Kartiasih, 2017) yang menyatakan bahwa volume ekspor berpengaruh signifikan terhadap daya saing. Hal ini menunjukkan bahwa dengan meningkatnya daya saing ekspor kakao olahan Indonesia ke negara tujuan utama ekspor, maka kakao olahan Indonesia akan lebih diminati oleh konsumen, sehingga akan meningkatkan permintaan kakao olahan oleh negara tujuan ekspor

Harga domestik kakao olahan (cocoa butter) Sumatera Utara menunjukkan pengaruh positif dengan nilai koefisien regresi sebesar 0.282 , artinya jika harga domestik meningkat sebesar Rp 1/ton ceteris paribus maka akan meningkatkan daya saing kakao olahan (cocoa butter) Sumatera Utara ke Pasar Singapura sebesar 0.282 persen. Hasil penelitian ini sesuai dengan penelitian (Wicaksono \& Kusnadi, 2016) yang menyatakan bahwa harga domestik memiliki nilai yang lebih rendah dibandingkan harga ekspor, namun cenderung memiliki nilai yang lebih tinggi dibandingkan harga impor. Jika harga domestik suatu produk di suatu negara lebih rendah dibandingkan harga ekspornya, maka eksportir akan cenderung mengekspor produk tersebut sehingga dapat meningkatkan daya saing produk. Namun, jika harga domestik suatu produk di suatu negara lebih tinggi dibandingkan harga produk yang sama di negara lain, maka importir akan cenderung mengimpor produk tersebut sehingga produk tersebut memiliki daya saing yang rendah.
Harga ekspor kakao olahan (cocoa butter) Sumatera Utara menunjukkan pengaruh positif dengan nilai koefisien regresi sebesar 0.842, artinya jika harga ekspor kakao olahan (cocoa butter) Sumatera Utara mengalami peningkatan sebesar $1 \mathrm{USD} /$ ton ceteris paribus maka akan meningkatkan daya saing kakao olahan (cocoa butter) Sumatera Utara ke Pasar Singapura sebesar 0.842 persen. Hasil penelitian ini sesuai dengan penelitian (Saragih, 2019) yang menyatakan bahwa peningkatan harga ekspor pasta kakao sebesar satu persen akan mengakibatkan peningkatan ekspor pasta kakao sebesar 0,321 persen dalam jangka panjang, cateris paribus. Hal ini diduga disebabkan karena eksportir pasta kakao akan tetap melakukan ekspor pasta kakao untuk mendapatkan keuntungan yang lebih besar, dan ekspor kakao pasta meningkat maka daya saing kakao pasta juga akan meningkat.Peningkatan harga ekspor menggambarkan mutu dan kualitas hasil kakao olahan Indonesia, semakin tinggi harga ekspor kakao olahan menandakan bahwa mutu dan kualitas hasil kakao olahan Indonesia semakin baik, sehingga nilai daya saingnya (nilai RCA) juga semakin tinggi di pasar internasional.

Harga ekspor kakao olahan (cocoa butter) Ghana menunjukkan pengaruh positif dengan nilai koefisien regresi sebesar 1.017, artinya jika harga ekspor kakao olahan (cocoa butter) Ghana mengalami peningkatan sebesar 1 USD/ton ceteris paribus maka akan meningkatkan daya saing kakao olahan (cocoa butter) Sumatera Utara ke Pasar Singapura sebesar 1.017 persen. Hasil penelitian ini sesuai dengan penelitian Hasil penelitian ini sesuai dengan penelitian (Tresliyana et al., 2018) yang menjelaskan bahwa Terdapat hubungan yang cukup tinggi antara daya saing biji kakao Indonesia dengan Ghana, dan daya saing kakao pasta Indonesia dengan Malaysia dan Belanda dalam perebutan pangsa pasar dunia. Hubungan tersebut semuanya positif dan ketiga negara eksportir tersebut memperebutkan pasar yang sama dengan Indonesia. Di pasar kakao butter dan kakao powder, Indonesia tidak memiliki 
korelasi dengan negara eksportir lainnya.

Kebijakan bea keluar menunjukkan pengaruh positif dengan nilai koefisien regresi sebesar 0.728 , artinya adanya kebijakan bea keluar, maka akan meningkatkan daya saing kakao olahan (cocoa butter) Sumatera Utara ke Pasar Singapura sebesar 0.728 persen. Hasil penelitian ini sesuai dengan penelitian (Habib, 2019) yang menyatakan bahwa kebijakan bea keluar terhadap ekspor biji kakao sebaiknya dipertahankan karena berdampak positif terhadap hilirisasi kakao Indonesia. Tarif bea keluar yang dikenakan secara seragam terhadap seluruh jenis biji kakao. Selain untuk kepentingan hilirisasi, kebijakan bea keluar juga diperlukan untuk pengendalian terhadap ketersediaan kakao untuk penggunaan dalam negeri. Penerapan kebijakan bea keluar pada dasarnya dilakukan untuk meningkatkan daya saing produk kakao hasil olahan di pasar internasional. Sehingga Penerapan kebijakan bea keluar hanya diperuntukkan untuk menghambat ekspor kakao dalam bentuk biji kakao. Biji kakao yang tidak diekspor akibat adanya bea keluar kemudian diolah dan dimanfaatkan oleh industri pengolahan dalam negeri, hasil pengolahan tersebut kemudian diekspor atau digunakan untuk kebutuhan dalam negeri. Peningkatan ekspor kakao pasca kebijakan bea keluar adalah hasil dari ekspor kakao dalam bentuk olahan.

\section{SIMPULAN}

Berdasarkan hasil analisis diatas maka kesimpulan yang diperoleh dalam penelitian daya saing kakao olahan Provinsi Sumatera Utara di pasar internasional adalah kakao olahan (cocoa butter) Provinsi Sumatera Utara memiliki daya saing yang kuat di Pasar Malaysia dan Pasar Singapura. Faktor-faktor yang mempengaruhi daya saing kakao olahan Provinsi Sumatera Utara di Pasar Malaysia dan Pasar Singapura adalah volume ekspor kakao olahan (cocoa butter) Sumatera Utara, harga domestik kakao olahan (cocoa butter) Provinsi Sumatera Utara, harga ekspor kakao olahan (cocoa butter)
Provinsi Sumatera Utara, harga ekspor kakao olahan (cocoa butter) Ghana, kebijakan bea keluar biji kakao berpengaruh positif dan signifikan terhadap daya saing kakao olahan (cocoa butter) Provinsi Sumatera Utara ke Pasar Malaysia dan Pasar Singapura.

\section{UCAPAN TERIMA KASIH}

Penulis mengucapkan terima kasih kepada semua pihak yang telah mendukung penelitian ini, khususnya Talenta USU yang telah membiayai penelitian ini serta Tim Studi yang telah bersama-sama melaksanakan penelitian ini serta kepada keluarga, temanteman dan semua pihak yang telah membantu dalam penelitian ini Semoga penelitian ini dapat bermanfaat bagi semua.

\section{DAFTAR PUSTAKA}

Abdullah, P., Alisjahbana, Armida, S., Effendi, N., B. (2002). daya saing daerah:konsep dan pengukurannya di Indonesia. Yogyakarta, BPFE.

Amirullah. (2015). Pengantar manajemen (fungsi-proses- pengendalian). Mitra Wacana Media.

Andini, D., Yulianto, E., \& Fanani, D. (2016). peningkatan daya saing ekspor produk olahan kakao Indonesia di pasar internasional(studi pada ekspor produk olahan kakao Indonesia tahun 20092014). Jurnal Administrasi Bisnis S1 Universitas Brawijaya, 38(2), 171-175.

Arsyad, A. (2011). media pembelajaran. Jakarta: PT Raja grafindo persada.

Asmarantaka, R. W. (2012). Pemasaran Agribisnis (Agrimarketing). Departemen Agribisnis, FEM-IPB. http://repository.ipb.ac.id/handle/123456 $789 / 65828$

Aulia, T., Suharyono, U., \& Yulianto, E. (2018). analisis daya saing ekspor biji dan produk olahan kakao Indonesia (periode tahun 2012-2016). Jurnal Administrasi Bisnis (JAB)|Vol, 62(2), 11-20.

Badry, S. I. (2013). analisis daya saing tekstil dan produk tekstil Indonesia di Amerika Serikat dengan pendekatan revealed comparative advantage dan constant 
market share. Universitas Negeri Semarang.

Ghozali, I. (2006). aplikasi analisis multivariate dengan program SPSS. Badan Penerbit Universitas Diponegoro.

Habib, G. B. (2019). dampak penerapan kebijakan bea keluar terhadap ekspor kakao Indonesia. Jurnal PKN STAN, Vol 3 , Nol, https://doi.org/http://dx.doi.org/10.3109 2/jpbc.v3i1.432

Hanafi, R. U., \& Tinaprilla, N. (2017). daya saing komoditas kakao Indonesia di perdagangan internasional. Forum Agribisnis, $\quad 7(1), \quad 1-20$. https://doi.org/10.29244/fagb.7.1.1-20

Harya, G. I. (2018). analisis faktor - faktor yang mempengaruhi dan upaya meningkatkan daya saing kakao Jawa Timur. Berkala Ilmiah AGRIDEVINA, 7(1), 77-92. https://doi.org/10.33005/adv.v7i1.1132

Indonesia, S. B. H. (2019). demand for chocolate products on the rise in Indonesia. Swiss Business $\mathrm{Hub}$ Indonesia. $\quad$ https://www.sge.com/en/article/globalopportunities/20191-c7-food-indonesiachocolate-products

Kalaba. (2012). analisis daya saing ekspor kakao Indonesia. Universitas Gajah Mada.

Makmun, S. (2012). dampak kebijakan bea keluar terhadap ekspor dan industri pengolahan kakao. Buletin Ilmiah Litbang Perdagangan, Volume 6 N, 16.

Maulana, A., \& Kartiasih, F. (2017). analisis ekspor kakao olahan Indonesia ke sembilan negara tujuan tahun 2000 2014 analysis of Indonesian cocoa exports to nine destination countries 2000 - 2014. Jurnal Ekonomi Dan Pembangunan Indonesia, 17(2), 103117.

Musfiah, P. Z. (2019). analisis daya saing kakao Indonesia dan faktor-faktor yang mempengaruhi. Universitas Muhammadiyah Surakarta.

Ragimun. (2012). analisis daya saing komoditas kakao Indonesia. Jurnal Pembangunan Manusia, Vol 6 No 2, 20.

Saragih, M. T. (2019). pengaruh penerapan bea keluar biji kakao terhadap daya saing serta ekspor produk kakao olahan Indonesia ke negara tujuan utama [IPB University]. http://repository.ipb.ac.id/handle/123456 789/100784

Tresliyana, A., Fariyanti, A., \& Rifin, A. (2018). daya saing kakao Indonesia di pasar internasional. Jurnal Manajemen Dan Agribisnis, 12(2), 150-162. https://doi.org/10.17358/jma.12.2.150

Wicaksono, R. P. K., \& Kusnadi, N. (2016). pengaruh penerapan bea keluar terhadap daya saing produk kakao Indonesia [Institut Pertanian Bogor]. https://repository.ipb.ac.id/handle/12345 $6789 / 86133$ 